\title{
Soudnictví v provincii Dalmatia Obecný přehled a vybrané otázky rozhodování hraničních sporů
}

\author{
David Termer
}

Kontaktni e-mail: david.termer@aktermer.cz

\begin{abstract}
Jurisdiction in the Roman Province Dalmatia
General Overview and Selected Issues of Decisions on the Boundaries between Municipalities
\end{abstract}

\begin{abstract}
:
The paper covers the administration of judiciary in the Roman province Dalmatia. The article focuses on the topic of the administrational division of the province into three conventus, jurisdiction of the provincial administrator and other officials, including municipal officials. An analysis of the preserved inscriptions depicting the decisions on the boundaries between municipalities follows. Most inscriptions capture disputes resolved under the cognitio extraordinaria, including disputes from the early Principate period.
\end{abstract}

Keywords: roman province; Dalmatia; public administration

Klíčová slova: římské provincie; Dalmácie; veřejná správa

DOI: $10.14712 / 2464689 X .2020 .18$

V rámci př́ípravy své disertační práce o provinčním zřízení římské provincie Dalmatia ${ }^{1}$ jsem provedl též výzkum organizace soudnictví v této provincii a s jeho výsledky bych rád nyní seznámil odbornou veřejnost prostřednictvím tohoto článku. Zajímavostí je zejména unikátní nápisový materiál týkající se hraničních sporů mezi jednotlivými municipii

1 Samostatná provincie Dalmatia vznikla rozdělením provincie Illyricum na dvě samostatné provincie Illyricum superius, tedy provincii Dalmatia, a Illyricum inferius, neboli provincii Pannonia, v průběhu tzv. Batonova povstání, a to v časovém intervalu, který můžeme určit rozmezím léto roku 6 n. 1. a podzim roku 8 n. 1 . TERMER, D. Provinční a městská správa v ř́mské provincii Dalmatia. Disertační práce, PF UK, Praha, 2019, s. 16 a násl. 
či domorodými obcemi, který poskytuje vzácný vhled do soudní praxe, byt' jen v jejím určitém výseku.

Jelikož Dalmácie byla v kontextu západní části římské říše provincií dosti standardní, může toto pojednání, v omezené míře, posloužit i jako určitý obecný pohled na provinční soudnictví v oblasti civilní. Studie je zaměřena na výzkum primárních pramenů a nemá ambici představit ucelený obraz stavu věcí a nahrazovat „bílá místa“ obecnými poznatky získanými z jiných provincií. Z hlediska časového je studie omezena lety 9 n. 1. - 395 n. 1., ale s ohledem na existující prameny přirozeně tíhne k období principátu.

\section{Organizace soudnictví, magistráti a jejich pravomoc}

\section{Conventus}

Z hlediska výkonu soudnictví všechna města i obce v provincii byly přiřazeny do jednoho ze třech konventů (conventus iuridici), které sídlily ve městech Scardona, Salona a Narona. Jednalo se nejen o jednotky soudní, ale i správní, zejména pro účely daňové a vojenské (nábor vojska). ${ }^{2}$

Rozdělení provincie do tří konventů se datuje do období po ukončení Batonova povstání v roce 9 n. 1. s tím, že se jednalo o postupný proces završený za Flaviovců, pravděpodobně za císaře Vespasiána, který vládl v letech 69 až 79 n. 1 . Konventy lze považovat za územně-správní mezičlánky mezi centrální mocí reprezentovanou správcem provincie a jednotlivými samosprávnými jednotkami v podobě municipií či domorodých civitates. $^{3}$ Principiálním literárním pramenem pro poznání dělení území provincie na jednotlivé konventy je Pliniova Historia naturalis. ${ }^{4}$

Na základě tohoto pramene lze tedy situaci zrekonstruovat následovně:

Conventus Scardonitanus: Civitas Iapodů a 14 civitates kmene Liburnů.

Conventus Salonitanus: civitates Delmatů (342), Deurů (22), Ditionů (239), Maezeiů (269) a Sardeatů (52).

2 WILKES, J. J. Dalmatia. Cambridge, Mass.: Harvard University Press, 1969, s. 288.

3 STARAC, A. The countryside in Liburnia. In: DAVISON, D. - GAFFNEY, V. - MARIN, E. (ed.). Dalmatia. Research in the Roman Province 1970-2001. Papers in honour of J. J. Wilkes. Oxford: Archaeopress, 2006, s. 107 a násl.

$4 \quad$ Plin. HN 3, 139: ... Conventum Scardonitanum petunt Iapudes et Liburnorum civitates XIIII, ex quibus Lacinienses, Stulpinos, Burnistas, Olbonenses nominare non pigeat. ... 142. petunt in eam (Salonam) iura viribus discriptis in decurias CCCXLII Delmatae, XXV Deuri, CCXXXVIIII Ditiones, CCLXVIIII Maezei, LII Sardeates... Narona colonia tertii conventus a Salona LXXXV p., adposita cognomins sui fluvio a mari XX p. M. Varro LXXXVIIII civitates eo ventitasse auctor est. 143. Nunc soli prope noscuntur Cerauni decuriis XXIIII, Daversi XVII, Desitiates CIII, Docleatae XXXIII, Deretini XIIII, Deraemistae XXX, Dindari XXXIII, Glinditiones XLIIII, Melcumani XXIIII, Naresi CII, Scirtari LXXII, Siculotae XXIIII populatoresque quondam Italiae Vardaei non amplius quam XX decuriis.

„139. Do soudní oblasti (conventus) se sídlem ve městě Scardona, se ubírají Iapodové a 14 obcí (civitas) Liburnů, z nichž by mě mrzelo nejmenovat obec Latiniensů, Stulpinů, Burnistů a Olbonensů. ... 142. Směřují tedy tam (do Salony) právní nároky náležející lidu rozdělenému do 342 dekurií Delmatů, 25 dekurií Deurů, 239 dekurií Ditionů, 269 Maezeiů a 52 dekurií Sardeatů. ... Kolonie Narona, sídlo třetího konventu, je od Salony vzdálena 85 mil a spojena s mořem řekou, od níž si vzala své jméno po 20 mílích. M. Varro je autorem výroku, že do tohoto konventu náleželo 89 obcí. 143. Nyní jediné známé jsou obce (civitas) Cerauniů mající 24 dekurií, Daversiů mající 17 dekurií, Desitiatů mající 103 dekurií, Docleatů mající 33 dekurií, Deretinů mající 14 dekurií, Deramistů mající 30 dekurií, Dindarů mající 33 dekurií, Glinditionů mající 44 dekurií, Melcumanů mající 24 dekurií, Naresů mající 102 dekurií, Scirtarů mající 72 dekurií, Siculotů mající 24 dekurií a obec bývalých plenitelů Itálie Vardaeů čítající ne více než 20 dekurií.“ 
Conventus Naronitanus: civitates Daesitiatů (103), Daversiů (17), Docleatů (33), Glinditionů (44), Melcumanů (24), Naresů (102), Pirustů rozdělených na Scirtary (72), Cerauny (24) a Siculoty (24), Vardaeů (20), Daraemistů (30), Dindarů (33) a Deretinů (14). ${ }^{5}$

Údaje v závorce uvádějí počet nižších administrativních jednotek nazývaných Pliniem decuriae. Civitates byly členěny na dekurie z důvodů administrativních a daňových. ${ }^{6}$

Zajímavým údajem je Pliniova zmínka o tom, že historik Varro zhruba o sto let dříve uváděl pro konvent se sídlem v Naroně počet domorodých kmenů a jejich správních jednotek (civitates) ve výši 89 . Snížení počtu těchto civitates domorodého obyvatelstva na 16 (počítáme-li rozdělení kmene Pirustů na tři civitates) je výmluvným dokladem rychlé centralizace moci a konsolidace území v průběhu pozdní republiky a raného principátu. ${ }^{7}$

K těmto domorodým civitates je třeba připočítat ještě jednotky s municipálním statusem nalézající se na území daného konventu, jejichž počet se v průběhu doby zvyšoval. V rámci konventu se řešily všechny soudní pře, které nespadaly do kompetence municipálních úředníků (viz níže) či speciálních úředníků centrální moci (např. procuratores, defensores civitatis). Část soudní agendy menšího významu byla vyřizována přímo municipálními magistráty. Jednalo se o duumviri iure dicundo a aediles př́padně quattuorviri iure dicundo.

Hranice mezi konventy lze dle J. J. Wilkese definovat následovně. Rozmezí mezi conventus Salonitanus a conventus Scardonitanus vedlo po linii mezi kmeny Iapodů a Maezaeiů a dále jižně po hranici mezi kmeny Liburnů a Delmatů. Podle geografických bodů by se dalo definovat od severu k jihu těmito markanty: město Prijedor, údolí řeky Sana, průsmyk Strmica, řeka Krka až k jejímu ústí. Hranice mezi conventus Salonitanus a conventus Naronitanus není tak dobře určitelná. Od severu $\mathrm{k}$ jihu vedla po linii mezi kmeny Maezeiů a Daesitiatů, tedy po rozvodí mezi povodími řek Vrbas a Bosna, dále po horských vrcholech Dinárského pohoří Vranjica, Čvrsnica a Čabulja, po hranici mezi kmeny Delmatů a Ardiaeiů jižně od municipia Novae, a končila dosažením mořského břehu v oblasti Makarské riviéry. ${ }^{8}$

Tyto soudní konventy nelze zaměňovat s dalšími konventy souběžně existujícími, což byly conventus civium romanorum. Jednalo se o původní obce italských přistěhovalců na území provincie, které později obdržely municipální status.

\section{Správce provincie a jemu podřizení soudci}

Hlavní soudní pravomoc v provincii byla soustředěna v rukách správce provincie, který kumuloval moc náležející tradičně prétorům městskému a cizineckému. Správci provincie ${ }^{9}$ Dalmatia měli status legati Augusti pro praetore, rekrutovali se ze senátního stavu, a to

5 WILKES, Dalmatia, s. 156, 157. J. J. Wilkes zmiňuje 22 dekurií u civitatis Deurů, Plinius st. však uvádí počet 25 dekurií pro tuto obec. Plin. $H N 3,142$.

6 WILKES, J. J. The Danubian and Balkan provinces. In: BOWMAN A. - CHAMPLIN E. - LINTOTT, A. (eds.). The Cambridge ancient history. 2. přeprac. vyd. Cambridge: Cambridge University Press, 2010, díl X, s. 576.

$7 \quad$ Plin. $H N 3,142$.

8 WILKES, Dalmatia, s. 176, 177.

9 D. 1,18,1 (Macer 1 de off.praesid.): Praesidis nomen generale est eoque et proconsules et legati Caesaris et omnes provincias regentes, licet senatores sint, praesides appelantur: proconsulis appelatio specialis est. „Označení správce je obecné, a proto se tak označují jak prokonsulové a císařští legáti, tak všichni správci provincií, třebas by to byli i senátoři. Označení prokonsul je speciální.“ Překlad převzat z knihy Digesta seu pandectae. Tomus I, liber I-XV. Fragmenta selecta. Praha: Karolinum, 2015, s. 215. 
zásadně z jedinců, kteři již měli za sebou pozici konzula v rámci cursus honorum. Najdou se však i př́iklady správců pretoriánských. Zhruba od 2. poloviny 3. století, za vlády císaře Galliena, ${ }^{10}$ dochází ke změně a nadále jsou jako správci vysíláni členové jezdeckého stavu s titulem preases provinciae. ${ }^{11}$

Správcům náleželo právo vydávat (prétorský) edikt coby základní právní pramen, podle kterého hodlal správce vykonávat spravedlnost na území svěřené provincie. ${ }^{12}$ Traduje se, že vývoj provinčních ediktů skončil za vlády císaře Hadriána vydáním „věčného ediktu“ (edictum perpetuum) a provinční edikt posléze ztrácel na významu spolu s ústupem formulového procesu a jeho plného nahrazení procesem kogničním. Žádné konkrétní poznatky o provinčních ediktech vydaných správci provincie Dalmatia se nezachovaly.

Digesta uvádějí další pravomoci správce v oblasti soudnictví. Správce má ve všem úplnou soudní pravomoc. ${ }^{13}$ Imperium správce neztrácí, ani když se zřekne svého úřadu. ${ }^{14}$ Tato pravomoc (jakož i ostatní pravomoci) vznikají správci překročením hranice provincie a vykonává je až do př́ichodu svého nástupce. Provincie nikdy nemůže být ani na okamžik bez svého správce, jelikož jen jeho prostřednictvím je vykonávána státní moc, správce je totiž držitelem impéria. ${ }^{15} \mathrm{Kde}$ je zapotřebí vydání rozhodnutí (decretum), nelze věc vyřešit př́ípisem (libellum). Správce má dohlížet na to, aby žaloby podávali jen ti, kdo jsou $\mathrm{k}$ tomu oprávněni v souladu s jeho ediktem. Má být zárukou dostupnosti spravedlnosti i pro méně majetné a obecně lid nižšího společenského postavení. Ženám, nezletilým, z jiných důvodů „slabým“ a těm, kteří nejsou při smyslech, má ustanovit advokáta ex offo. ${ }^{16}$

Výzkumem ohledně správců provincie Dalmatia jsem se podrobně zabýval v rámci své disertační práce. Podle mých zjišsění je k dnešnímu dni identifikováno 43 správců, kteří v této provincii působili do roku 395 n. $1 .{ }^{17}$

Správce navštěvoval sídla konventů v určených soudních obdobích. Zde se vyřizovala veškerá soudní agenda př́íslušející k rozhodování centrální státní moci. Mezi hlavní pomocníky správce při výkonu soudní pravomoci patřili legati. Jednalo se v císařských provinciích o legati iuridici, jejichž ekvivalentem v senátních provinciích byli legati pro praetore, kteří vykonávali správcem delegovanou soudní pravomoc. ${ }^{18}$ Postavení těchto magistrátů a př́klady jejich kompetencí máme k dispozici v Digestech. ${ }^{19}$ Pro provincii Dalmatia není takový úředník primárními prameny doložen, ${ }^{20}$ stejně jako další magistrát, který byl správci ku pomoci při vyřizování soudní agendy. Jednalo se o iudex pedaneus, který měl svěřenou trvalou agendu vyřizování drobných soudních sporů. ${ }^{21}$

Další osobou, na níž správce delegoval svou soudní pravomoc, byl iudex datus (resp. iudex delegatus). Jednalo se o osobu, případně osoby, které správce pověřoval ad hoc

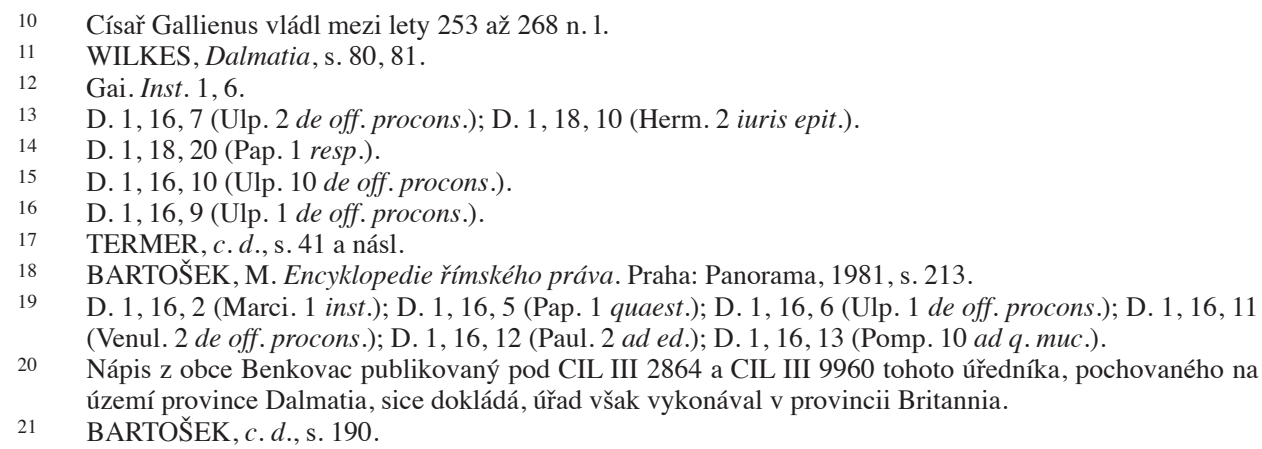


rozhodnutím konkrétní věci. Iudex datus je doložen v provincii četnými nápisy, kterými se podrobně zabývám v pojednání o hraničních sporech.

\section{Ostatní magistráti s jurisdikcí zastupující centrální moc}

Procuratores definuje M. Bartošek obecně jako správce cizího majetku a ve správním právu jako úředníka, který trvale pečoval o císařský majetek nebo o některý úsek státní správy, zejména o veřejné finance ( $p$. fisci, $p$. a rationibus), o zastupování císaře ve věcech správních a vojenských ( $p$. Augusti, $p$. Caesaris), o dědické záležitosti ( $p$. hereditatium), těžbu kovů ( $p$. patrimonii), veřejné stavby a budovy ( $p$. operum publicorum) a o císařùv majetek (p. patrimonii Caesaris), od Septima Severa $p$. (magister) rei privatae. ${ }^{22}$

Jak se podává již z výše řečeného, úruedníci pod shodným titulem procuratores vykonávali v provincii často zcela odlišné funkce. Na jedné straně stál procurator zastupující res privata, tedy pečující zejména o nemovitý majetek císaře, jehož kompetence popisuje Corpus iuris civilis. ${ }^{23} \mathrm{Na}$ druhé straně byli prokurátoři spadající pod sacra largitionum působící v oblasti těžby kovů a jiných hospodářských odvětví kontrolovaných státem. Wilkes uvádí, že procuratores, kteří byli jmenováni z jezdeckého stavu, měli obdobné officium pro soudní účely jako správce provincie a k dispozici jim byla i familia sestávající z otroků a propuštěnců pro finanční záležitosti a vedení účtů. ${ }^{24}$

Za časů císaře Trajána jeden procurator na území provincie Dalmatia rozhodoval hraniční spor a určil hranice mezi vojenským prostorem v Burnumu - prata legionis a sousedícími lesními pozemky. ${ }^{25}$

V heidelbergské nápisové databázi je registrováno dalších dvacet devět nápisů nalezených na území province Dalmatia, na nichž se zachycuje osoba s titulem procurator. $\mathrm{Z}$ nich pouze několik lze s vysokou pravděpodobností identifikovat jako obecného prokurátora $\mathrm{v}$ rámci správy pokladny res privata. Jako př́klad lze uvést nápis ze Salony datovaný lety 101-130 n. 1.26 Naproti tomu u nápisu ze Srebrenice (Domavium), který je datován lety 201-250 n. 1., lze usuzovat z místa nálezu, významného hornického města, že se jednalo o procurator metallorum spadajícího pod úřad sacra largitionum. ${ }^{27} \mathrm{~K}$ tomuto druhu je třeba podle mého mínění přiřadit většinu publikovaných nápisů, když často je zde souvislost $\mathrm{s}$ těžbou drahých kovů vyjádřena prrímo, jako např. na nápisu $\mathrm{z}$ obce Zvornik v Bosně a Hercegovině datovaného lety $217-218$ n. $1 .,{ }^{28}$ nebo lze tuto prŕíslušnost dovodit

$22 \quad$ BARTOŠEK, $c . d .$, s. 265, 266.

23 D. 1, 19, 1 (Ulp. 16 ad ed.); D. 1, 19, 2 (Paul. 5 sent.); D. 1, 19, 3 (Call. 6 de cogn.).

24 WILKES, Dalmatia, s. 122.

25 CIL III 13250; Viz rozbor tohoto nápisu níže v rámci pojednání o hraničních sporech (nápis 20).

$26 D($ is) [M(anibus)] / L(ucio) Valerio / [---] proc(uratori) Aug(usti) p[rov(inciae) Dalmat(iae)] / praef(ecto) classis [--- praef(ecto) alae] / Moesicae trib(uno) [mil(itum) leg(ionis) ---] / praef(ecto) coh(ortis) I Tyr[ior(um) ---] / Gal(eria) Niger pro[---] / consobr[ino posuit]. CIL III 8716, místo nálezu Salona, datace $101-300$ n. 1 .

27 I(ovi) O(ptimo) M(aximo) / Iunoni R(eginae) / M(arcus) Arrius / [-]nianus / proc(urator) Aug(usti) / pro sal(ute) [sua] / et suoru[m] // v(otum) l(ibens) s(olvit). CIL III 12725, místo nálezu Srebrenica, datace 201-250 n.1.

28 [[Imp(eratore) [Cae]s(are) M(arco) O[p]ell(io) Sever(o)]] / [[M[ac]rin[o Pio Fel(ici)] Au[g(usto)] p(ontifice) m(aximo) trib(unicia)]] / [[p[ot(estate) co(n)]s(ule) [---]I?I?I?I?[---]I?]] / [[[-]I?[--]M?[---] N[---]I?[---]A?N?S]] / macellum vi ignis conflagr $<a>$ tum curante Val $<e>$ (erio) Supero $v($ iro) e(gregio) proc(uratore) arg(entariarum) / $r$ (es) $p$ (ublica) Dom(aviana) ad pristinam / faciem restituit XXI Kal(endas). CIL III 8363, místo nálezu Zvornik, datace 217-218 n. 1. 
z místa nálezu. Tento názor je podpořen článkem A. Škerga, který se podrobně zabývá těžbou a zpracováním cenných kovů v provincii Dalmatia. ${ }^{29}$

Curator. V rámci správy provincií se ukázalo jako nezbytné vykonávat kontrolu nad místní samosprávou ze strany státu, a to dohledem na místě samém. Toto nebylo v silách správce provincie, ani členů jeho úřadu, a tak císař jmenoval speciální úřredníky s touto agendou. Jedním z hlavních úredníků vykonávajících tento dohled byl curator rei publicae. Tito magistráti byli vybíráni z různých sociálních vrstev. Vedle senátorů tuto funkci vykonávali členové jezdeckého stavu, ale i členové municipální aristokracie sousedních měst. Tito funkcionáři se pravidelně vyskytovali ve všech typech provincií ve východní i západní části impéria. Jejich činnost nezasahovala do všech oblastí obecní správy, zaměřovali se spíše na finanční hospodaření obcí. Jednalo se o ad hoc jmenované úředníky s omezeným věcným i časovým mandátem, kteří neměli nahrazovat obecnou správu provincie, $\mathrm{k}$ níž byl povolán její správce. ${ }^{30}$

Poněkud odlišně vidí úlohu těchto magistrátů A. H. M. Jones, který uvádí, že do konce třetího století curatores zastínili úlohu lokálních úředníků a do vlády Diokleciána mělo každé město trvalého kurátora. Původně byli jmenováni za účelem kontroly finančního hospodaření obcí, ale jejich úloha postupně masivně vzrostla. V menších městech byli do této funkce postupně jmenováni vedoucí činitelé obce a tento úřad se stal pravidelnou součástí jejich kuriální kariéry a na jmenování se podílel ordo decurionum. Přesto se i nadále jednalo o císařského, nikoliv municipálního úrúedníka. ${ }^{31}$

J. J. Wilkes uvádí dva curatores, kteří byli činní v provincii Dalmatia: ${ }^{32}$

- ... curator reipublicae Flanatium, jednalo se o obyvatele blízké kolonie Pola (Pula), který byl jmenován coby kurátor municipia Flanona v pozdním druhém století. ${ }^{33}$ Nápis pochází z Puly a je datován 101-200 n. 1.

- curator Arben/si(um) Met(u)lensi(um) / Splonista(rum) / Malvesati(um). Místo nálezu Pljevlja, datace 101-200 n. 1. ${ }^{34}$ Nápisem se detailně zaobírá M. Mirkovičová se závěrem, že tento úředník pověřený císařem, aby reguloval finance a placení daní v provincii, byl takto činný ve čtyřech obcích, které nelze přesně lokalizovat. Arbenses by mohli být obyvatelé ostrova Arba (Rab), Metlenses obyvatelé municipia Metulum, Malvesatii pak obyvatelé municipia Maluesa. Tato tři místa se sice nacházejí na území provincie Dalmatia před jejím dělením, ale jsou od sebe značně vzdálena, a proto by se muselo jednat o sukcesivní výkon tohoto úřadu v několika obcích po sobě. Splonistae se pak váže

29 ŠKERGO, A. The economy of Roman Dalmatia. In: DAVISON, D. - GAFFNEY, V. - MARIN, E. (ed.). Dalmatia. Research in the Roman Province 1970-2001. Papers in honour of J. J. Wilkes. Oxford: Archaeopress, 2006, s. 149 a násl.

30 ECK, W. Provincial administration and finance. In: BOWMAN, A. - GARNSEY, P. - RATHBONE, D. (ed.). The Cambridge ancient history. 2. přeprac. vyd. Cambridge: Cambridge University Press, 2013, díl XI, s. 278 a násl.

31 JONES, A. H. M. The later Roman empire. Oxford: Basil Blackwell,1964, díl II, s. 726 a násl.

32 WILKES, Dalmatia, s. 195, 266 a 282.

33 Cn(aeo) P[a]pirio / Cn(aei) [f(ilio) V]el(ina) / Sec[un]din(o) / II(viro) [II]ir(o) q(uin)q(uennali) / patro[no e]t praef(ecto) / coll(egii) [fab]ror(um) Pol(ensium) / cura[tor]i rei p(ublicae) / Fla[nati]um / M(arcus) Helv[ius Her]mias / amic[o dig]niss(imo) / l(ocus) d(atus) [d(ecreto)] d(ecurionum). CIL V 60, místo nálezu Pula, datace 101-200 n. 1.

34 Serapidi / et Isidi M(arcus) / Ulp(ius) Gellia/nus eq(ues) R(omanus) / cur(ator) Arben/si(um) Met(u) lensi(um) / Splonista(rum) / Malvesati(um). AE 1948, 0242; ILJug 73, místo nálezu Pljevlja, datace 101-200 n. 1 . 
k municipiu Splonum. M. Mirkovičová v této souvislosti rekapituluje dosavadní výzkumy ohledně lokalizace tohoto municipia a dále vědeckou diskusi týkající se otázky, zda municipium Splonum je tím muncipiem S., které se nachází v okolí Plevle a kterému věnuje celou svojí monografii. ${ }^{35}$

V nápisové databázi heidelbergské univerzity je evidováno dalších šest nápisů dokládajících tohoto úředníka na území provincie Dalmatia.

První z těchto nápisů je věnován dvěma kuriálům z kolonie Salona, když jeden z nich byl zároveň během svého života curator rei publicae Splonistarum. Jedná se tedy již o druhého curator doloženého pro tuto obec. Nápis pochází ze Solinu a je datován 71-150 n. 1.36

Další čtyři jsou ze Solinu či Splitu a dva se týkají hlavního města Salona, u dvou z nich není zřejmé, kde byla funkce kurátora vykonávána. Datace nápisů je uvedena v poznámce za textem nápisu. ${ }^{37}$

Poslední nápis ze Sinje uvádí nejvyššího kurátora římských občanů v provincii Dalmatia. Datace nápisu je poměrně raná ve srovnání s ostatními nápisy, když vznik tohoto nápisu je kladen mezi roky 42-100 n. $1 .{ }^{38}$ Lze tedy usuzovat, že se jednalo o ad hoc úředníka jmenovaného císařem pro všechna města $\mathrm{v}$ provincii.

35 MIRKOVIČ, M. Municipium S. Bělehrad: Filozofski fakultet, Univerzitet u Beogradu, 2013, s. 59 a násl.

36 T(ito) Flavio / T(iti) fil(io) Tro(mentina) / Agricolae / decur(ioni) col(oniae) Sal(onitanae) / aedili IIvir(o) iure / dic(undo) dec(urioni) col(oniae) Aequi/tatis IIvir(o) q(uin)q(uennali) disp(unctori) / municipi(i) Riditar(um) / praef(ecto) et patron(o) coll(egii) / fabr(um) ob merita eius coll(egium) / fabr(um) ex aere conlato / curatori rei pub(licae) Splonis/\{s\}tarum trib(uno) leg(ionis) X g(eminae) p(iae) f(idelis) // T(ito) Vettio / Augustali / decurioni / colon(iae) Salon(itanae) / quaestori / aedili IIvir(o) / iure dic(undo) praef(ecto) / et patrono coll( egii) / fabr(um) ob merita / eius coll( egium) fabr(um) / ex aere conlato. CIL III 2026, místo nálezu Solin, 71-150 n. 1.

37 [[-----]]] / [ [Petronio?]] / Iun[i]ori c(larissimo) v(iro) / cu[r]atori / [ope]rum / [pub]licorum / [cur]atori / [aqua]e et / [cur]atori / [Min]uciae / [r(es) p(ublica)] S(alonitanorum) / [[[------]]]. AE 1961, 302; ILJug 677, místo nálezu Solin, 171-250 n. 1.

Aur(elio) Valerino excepto/ri Impp(eratorum) in officio memo/ri(a)e qui aput(!) civitatem / Nicomediensium fat/i munus complevit / vixsit(!) annis XXXII et [IVI]] / me(n)s(ibus) Aur(elius) Leontius vir / docen(arius) (!) et dec(urio) col(oniae) Salon(itanorum) / ex curatoribus eiusd/em civitatis filio dulc/issimo adque(!) obsequ/entissimo pater infeli/x qui quod primo mihi / hoc facere debuerat e/go feci. AE 1961, 308; ILJug 126, místo nálezu Solin, datace 313-324 n. 1.

Si $q(u)$ is super hunc corpus alium / corpus ponere volueret(!) in/feret ec(c)lesiae argenti p(ondo) X / Fl(avius) Theodotus curator rei p(ublicae) / Peregrinum filium in lege / sancta christiana collo/cabi(!) eum depos(i)tio(ne) / Domnionis die III Kal(endas) De/(c)enbris(!) con(sule) Antonio. CIL III 9508, místo nálezu Solin, datace 29.11.382 n. 1.

[--- L?] ]euntius(!) v(ir) r(espectabilis?) pr(ae)p(ositus)(?) p[---?] / [---]et ex curatori[b(us)] / [---] mihi posuit an/[n]orum [---?]LXXX. MARIN, E. Salona 4. Inscriptions de Salone chrétienne, IVe-VIIe siècles. Ŕím - Split: Ecole Française de Rome, 2010, 813-814, č. 451, místo nálezu Split, datace 301-400 n. 1.

38 Sex(tus) Iu[lius Sex(ti) f(ilius)] / Ani(ensis) Silva[nus Foro Iuli(i)] / summus c[urat(or) c(ivium) R(omanorum) prov(inciae) Dalm(atiae)] / suffragio [eorum factus ex cent(urione)] / leg(ionis) VII C(laudiae) p(iae) f(idelis) aed[ilis col(oniae) Claudiae Aequi ab] / ordine primus [post col(oniam) deduct(am) creatus] / IIIIvir i(ure) d(icundo) pont(ifex) [in col(onia) Salonitan(orum)] / in ag <ro $>p$ (edes) [--- in fronte p(edes) ---] / h(oc) s(epulcrum) h(eredem) [n(on) s(equetur)]. CIL III 2733, místo nálezu Sinj, datace $42-100$ n. 1 . 
Pro úplnost je třeba ještě učinit zmínku o nápisu nalezeném mimo provincii Dalmatia, ${ }^{39}$ který pojednává o osobě Quinta Pomponia Rufa, který byl i správcem této provincie. ${ }^{40}$ Tato skutečnost vyplývá z předmětného nápisu, stejně jako fakt, že vykonával i úřad kurátora. $\mathrm{Z}$ nápisu se bohužel již nedozvídáme místo výkonu této jeho funkce.

Corrector byl císařský úředník, který vykonával dozor nad municipii. ${ }^{41}$ Tento magistrát se objevuje již za vlády Vespasiana, někdy se též označuje jako legatus. Correctores byli ad hoc jmenovaní úředníci za účelem prověření stavu věcí, zejména finančních, v konkrétní obci, at' šlo o municipium, colonia či civitas a za účelem zjednání nápravy v př́ípadě zjištěných nedostatků. Měli impérium delegované na ně přímo císařem a rekrutovali se ze senátního stavu. Jejich výskyt je zaznamenán převážně ve východní části říše. ${ }^{42} \mathrm{Z}$ nápisů není doložen žádný corrector pro území provincie Dalmatia.

Defensor civitatis. M. Bartošek definuje tohoto úředníka (synonynum defensor plebis) tak, že se jednalo od 4. století o císařského úředníka, jehož úkolem bylo chránit zájmy nejchudších občanů proti mocným (potentes), který však postupně nabyl právo dozoru nad nižšími provinčními úředníky a také nabyl soudní pravomoci v drobných záležitostech. ${ }^{43}$ Dle J. J. Wilkese defensores vznikli za císaře Valentiniana I. (367-375 n. 1.) za účelem ochrany provinciálů proti excesům bohatých vlastníků pozemků při výběru daní. ${ }^{44}$ Defensor civitatis působil též jako soudce v menších věcech, proti jehož rozhodnutí bylo možné se odvolat. ${ }^{45} \mathrm{Z}$ nápisů není doložen žádný defensor civitatis pro území provincie Dalmatia.

\section{Municipální magistráti s jurisdikcí}

Duumviri (duoviri), Quattuorviri. Dle Bartoškovy encyklopedie (heslo duoviri iuri dicun$d o)^{46}$ se jednalo o municipální obdobu římských konzulů a prétorů, tj. měli vlastní soudní pravomoc; spolu s duoviri aediles tvořili společný úřad quattuorviri. ${ }^{47}$ Původně se lze setkat i v nápisech z Dalmácie s magistraturou typu quattuorviri, později došlo k oddělení edilů z této čtveřice a jako hlavní představitelé města zůstávají duumviri. V roce pětiletého období, kdy byl připravován daňový census, se tato funkce doplňovala prrívlastkem quinquenales, přičemž takto označení úřredníci měli na starosti vyhotovení požadovaného soupisu osob a majetku a jeho včasné odevzdání centrálním úřadům (census). ${ }^{48}$ Dle A. H. M. Jonese byly v západní části říše standardně v čele měst duumviri, kteří předsedali radě, vykonávali tu část soudnictví, která městu náležela, a organizovali hry. ${ }^{49}$

Q(uintus) Pomponius Rufus co(n)s(ul) pont(ifex) sodal(is) Fla(vialis) cur(ator) oper(um) publicor(um) leg(atus) Aug(usti) / pro pr(aetore) provinc(iarum) [M]oesiae Dalmat(iae) Hisp(aniae) leg(atus) leg(ionis) $V$ prae(fectus) orae marit(imae) Hispan(iae) citer(ioris) Gallia[e] / N[a]rbon(ensis) bello qu[od] Imp(erator) G[a]lba pro [re p(ublica)] gessit proco(n)s(ul) provinc(iae) Africae per L(ucium) Asinium Ru[fum] / [leg(atum) p]ro [pr(aetore) ------. CIL VIII 13, místo nálezu Al Khums, datace neuvedena; CIL XVI 38; PIR III s. 79, č. 561.

40 Q. Pomponius Rufus, konsulem suff. září až prosinec 95 n. 1., funkční období správce provincie Dalmatia v letech cca 92-94 n. 1.

41 BARTOŠEK, $c . d$., s. 122.

42 ECK, $c . d .$, s. 278 a násl.

43 BARTOŠEK, $c . d .$, s. 130.

44 WILKES, Dalmatia, s. 423.

45 JONES, $c$. $d$., díl II, s. 726 a násl.

46 Vedle tvaru iuri dicundo je přípustný i tvar ablativní iure dicundo, který se mi jeví v zahraniční odborné literatuře jako frekventovanější a je používán i v epigrafice.

47 BARTOŠEK, $c . d$., s. 140.

48 Tab. Heracl. 142-156.

49 JONES, $c . d$., díl 2, s. 725. 
Jednalo se o nejvyšší municipální magistráty a náležela jim tedy obecně veškerá exekutivní moc, která nebyla svěřena nižším úředníkům a v omezené míře i pravomoc soudní. Ani Tabula Heraclensis, ani Lex irnitana v dochované podobě bohužel neobsahují ucelený oddíl, kde by se popisovaly kompetence duum(quattuor)viri, totéž lze konstatovat ve vztahu k padesáté knize Digest. Jednotlivé kompetence však z pramenů doložit lze. Jedná se např. o právo rozhodovat o městských financích, ${ }^{50}$ rozhodovat o veřejných cestách a kanalizacích ${ }^{51}$ a v neposlední řadě vykonávat svěřenou část soudnictví. ${ }^{52}$

V nápisové databázi heidelbergské univerzity se nachází pro provincii Dalmatia 203 nápisů, na nichž jsou tito magistráti uvedeni (200 při zadání slova IIvir, tyto nápisy zahrnují i IIIIviri, jeden nápis při zadání slova quattuorvir a dva nápisy při zadání duumvir). V poznámce se uvádějí čtyři prŕiklady těchto nápisů. ${ }^{53}$

Aediles. M. Bartošek je stručně charakterizuje pod heslem duoviri aediles jako municipální obdobu římských edilů ${ }^{54} \mathrm{~A}$. H. M. Jones uvádí mezi úkoly těchto magistrátů, kteří působili vždy ve dvojici, organizaci řádného plnění městských veřejných služeb, čištění ulic a kanálů, dodávku vody a údržbu a kontrolu městského trhu. ${ }^{55}$ Podle Tabula Heraclensis péče o tržiště, veřejné cesty, veřejná prostranství a svatyně náležela do kompetence edilů. ${ }^{56}$ Lex Irnitana o kompetencích municipálních edilů uvádí, že měli na starosti zásobování obilím, správu svatyní a svatých míst, správu cest, kanálů a trhů, kontrolu vah, kontrolu nočního klidu a pořádku a další činnosti, které jim byly uloženy kuriály k plnění. Dále měli edilové i omezenou moc soudní, resp. pravomoc na svěřeném úseku správy. ${ }^{57}$ Jak bylo uvedeno již shora, voleni do funkce byli sborem kuriálů (ordo decurionum) v počtu dvou, a to na dobu jednoho roku.

V nápisové databázi heidelbergské univerzity se nachází pro provincii Dalmatia šedesát šest nápisů, na nichž jsou tito magistráti uvedeni. Jeden edil působící v Saloně byl shora uveden coby corrector (CIL III 2026). Dalším prríkladem je edil z kolonie Aequum. Před

50 Eisque (quaestoribus) pecuniam communem municipum eius municipii exigendi, erogandi, custodiendi, atministrandi, dispensandi arbitratum II virorum ius potestasque esto. Lex Irni. 3A 20. „Jim (kvestorům) náleží právo a moc obecní prostředky jejich municipia vybírat, vynakládat, střežit, spravovat a rozdělovat, a to podle rozhodnutí duumvirů." Další kompetence duumviri v otázkách finančních: Lex Irni. 8C 79.

$51 \quad$ Lex Irni.9A 82.

52 Lex Irni.9B 84, 85; 9C 86, 87; 10A 88-90; 10B 91-93.

$53[D(i s)] M($ anibus $) / /[M($ arco $)$ Na]evio Firmo / [dec]urioni col(oniae) / [Aequ]ensium aedili d/[uumvi]ro qui vixit ann(is) / [---] Naevio Natalioni / [patri ei]usd(em) M(arci) Naevi Fir(mi) / [qui vi]xit annis LXXX / [Cla]udia Syra / [mate]r filio piissim(o) / [et mari]to obsequentiss(imo) / p(osuit). AE 1925, 136; ILJug 1964, místo nálezu Hrvace, datace 101-200 n. 1.

Iulio Q(uinti) filio / CAFILIAIVLLIAF / d(uum)vir(o) i(ure) d(icundo) / <II>vir(o)TVIR quinq(uennali) / ex testamento iuss(it). CIL III 3130, místo nálezu Krk, bez uvedení datace.

Florentino plus quam / delicias Verae moest(a)e ma/[tri]s tuetur(?) manenti cor/pus VS pater infelix a reposit(ione?) / [---] monumenti vice inscrib(endum) / [---]V[--- a]tque ip [s]o CEPE COL / [---] U[r] sinus unqu[am](!) / [---] Volceni(us) Nepos / qu[att]uorvir i(ure) d(icundo) q(uin)q(uennalis) / [---]VC[---]. CIL III 3004; CIL III 10026, místo nálezu Perusiš, datace 151-300 n. 1.

Sex(tus) Iu[lius Sex(ti) f(ilius)] / Ani(ensis) Silva[nus Foro Iuli(i)] / summus c[urat(or) c(ivium) R(omanorum) prov(inciae) Dalm(atiae)] / suffragio [eorum factus ex cent(urione)] / leg(ionis) VII C(laudiae) p(iae) f(idelis) aed[ilis col(oniae) Claudiae Aequi ab] / ordine primus [post col(oniam) deduct(am) creatus] / IIIIvir i(ure) d(icundo) pont(ifex) [in col(onia) Salonitan(orum)] / in ag $<$ ro $>A G C E$ p(edes) [--- in fronte p(edes) ---] / h(oc) s(epulcrum) h(eredem) [n(on) s(equetur)]. CIL III 2733, místo nálezu Sinj, datace 42-100 n. 1 .

54 BARTOŠEK, $c . d .$, s. 140.

55 JONES, $c . d$., díl 2, s. 725.

56 Tab. Heracl. 20-82.

57 Lex Irni.3A 19. 
vznikem této coloniae byl veterán Sextus Iulius Silvanus činný jako summus curator této předmunicipální organizace a následně působil coby aedil nově vzniklé coloniae. ${ }^{58}$ Další edilové, patrně z kolonie Narona, jsou doloženi nápisem z obce Janjina datovaným lety $1-150$ n. $1 .{ }^{59}$

\section{Rozhodování hraničních sporů v provincii}

Jednoznačně nejcennější poznatky o soudní agendě v provincii Dalmatia máme díky četným zachovalým nápisům, v nichž je zmínka o řešení hraničních sporů mezi municipii, př́padně i mezi domorodými obcemi (civitas). K dispozici máme celkem 21 takových nápisů, jejichž rozborem lze dojít alespoň malého vhledu do fungování soudnictví v provincii, byt' v jeho specifické převážně veřejnoprávní podobě.

V souladu se zaběhnutou praxí správce po vzniku provincie stanovil její vnitřní uspořádání v daných hranicích (forma provinciae). ${ }^{60} \mathrm{~V}$ provincii Dalmatia máme doklad o tomto uspořádání za správce Dolabelly (forma Dolabellina). ${ }^{61}$ Lze tedy dovodit, že za správce Dolabelly, na samém úsvitu existence provincie, ${ }^{62}$ došlo k základnímu vymezení správních okrski̊, resp. hranic mezi jednotlivými obcemi na území provincie. Toto základní vymezení se nadále opravovalo či zpřesňovalo individuálními právními akty, jak níže uvedeno.

Rozhodování o hranicích mezi jednotlivými samosprávnými jednotkami je třeba hodnotit jako rozhodování na pomezí výkonu soudnictví a administrativní správy a jak uvidíme při analýze dochovaných nápisů, je někdy obtížné vést tuto hranici přesně. Zároveň je však na místě zmínit notorietu, že v antice, stejně jako později ve středověku, nebyl kladen valný důraz na takové rozlišování, na rozdíl od moderního práva.

V dalším výkladu se pokusím dovodit pro jednotlivé kauzy, o který typ rozhodování se jednalo. Ve všech př́padech ani nepůjde o řešení sporu, nýbrž o prvotní vyměření hranic dle forma Dolabellina, resp. o pozdější hromadné přeměřování a nové ustanovení hranic z podnětu centrální moci. Najdeme i případ, kdy je zachycena mimosoudní dohoda stran o řešení sporu. Tam, kde má níže uvedené rozhodnutí podobu soudní jurisdikce, je třeba nastolit otázku, o jaký typ rrímského procesu se v každém konkrétním případě jedná, zda o proces formulový či kogniční.

Na počátku principátu v soukromých sporech ještě jednoznačně převažuje proces formulový, který byl pro spory římských občanů dokonce obligatorní. V provinciích však záhy nabývá vrchu proces kogniční, zejména pokud se jedná o př̀ mezi cizinci (peregrini).

58 Sex(tus) Iu[lius Sex(ti) f(ilius)] / Ani(ensis) Silva[nus Foro Iuli(i)] / summus c[urat(or) c(ivium) $R$ (omanorum) prov(inciae) Dalm(atiae)] / suffragio [eorum factus ex cent(urione)] / leg(ionis) VII C(laudiae) p(iae) f(idelis) aed[ilis col(oniae) Claudiae Aequi ab] / ordine primus [post col(oniam) deduct(am) creatus] / IIIIvir i(ure)d(icundo) pont(ifex) [in col(onia) Salonitan(orum)] / in ag $<$ ro $>p$ (edes) [-- in fronte p(edes) ---] / h(oc) s(epulcrum) h(eredem) [n(on) s(equetur)]. CIL III 2733, místo nálezu Čitluk, datace $42-100$ n. 1.

59 [C]alvidiae P(ubli)f(iliae) / [Se]cundae uxori / piissimae / [- An]naeus P(ubli)f(ilius) Tro(mentina) Aper / [aed]ilis IIIIvir i(ure) d(icundo) et / [- An]naeo P(ubli) f(ilio) Tironi / [ae]d(ili) IIIIvir(o) i(ure) d(icundo) et / [- An]naeo P(ubli) f(ilio) Apro / et [sib]i et suis. CIL III 8451, místo nálezu Janjina, datace 1-150 n. 1.

60 WILKES, Dalmatia, s. 456.

61 Leg(at-)] Aug(usti) pro pr[(aetore)] / [s]ecundum formam / Dolabellianam / restituit. ILJug 874, místo nálezu Benkovac, datace 117-138 n. 1.

62 P. Cornelius Dolabella P. f., konsulem v roce 10 n. 1., funkční období správce provincie Dalmatia v letech 14-20. Jednalo se $\mathrm{v}$ pořadí o třetího správce nově ustanovené provincie. 
Svěřené imperium správci provincie dovolovalo využít obou těchto procesních typů. ${ }^{63} \mathrm{Jak}$ uvidíme v dalším výkladu, nebyl proces kogniční v provinční správě opomíjeným institutem ani v době raného principátu.

Takřka všechny zachované nápisy lze najít na kamenných sloupech umístěných bud' na nově ustanovené hranici, nebo v centrech dotčených měst. Většina rozhodnutí vznikla za juliovsko-claudiovské dynastie, i když existují i nápisy dokládající taková rozhodnutí v pozdější době. ${ }^{64}$ Naprostá většina sporů se týká obcí - municipií - v oblasti Ravni Kotari (Liburnie) zhruba mezi řekami Krkou a Zrmanjou. Toto zjištění není překvapující, jelikož v daném prostoru se nacházelo celkem devět municipií (Corinium, Ansium, Nedinum, Sidrona, Asseria, Alveria, Varvaria, Scardona a Burnum) a nikde jinde v provincii nebyla taková hustota měst s municipálním statusem jako v dané oblasti.

Nápisy jsou níže řazeny v zásadě dle hlediska časového od nejstaršího k nejmladšímu. V prvním sledu se pojednává o nápisech z oblasti Ravni Kotari, kterých je většina. U těchto nápisů není vždy dodrženo chronologické řazení, nýbrž jsou k sobě primárně řazeny nápisy, které spolu věcně souvisí.

Pro větší přehlednost jsou nápisy číslovány (číslice je v závorce). Níže uvedený popis předmětných nápisů obsahuje u každé položky základní data jednotlivých kauz a stručný rozbor. Na konci pojednání se pak pokusím o určité zobecňující závěry.

(1) Půjdeme-li při výčtu rozhodnutí o hraničních sporech podle časové linie od nejstaršího k nejmladšímu, bude na místě začít u nápisu, který je umístěn v Zadarském muzeu, místem nálezu je obec Benkovac (Corinium). ${ }^{65}$ Nápis vlastně pojednává o dvou rozhodnutích, která se týkala hranice mezi municipii Corinium a Nedinum (Nadin) v oblasti nazývané Ravni Kotari.

První část nápisu (končící slovem Corienses) referuje o rozhodnutí S. T. Gemina, velitele sedmé legie, který určil (determinavit) hranice mezi těmito obcemi za správce Dolabelly. Otázkou je, zda se jedná o hraniční spor nebo administrativní úkon při prvotním vytyčování hranic za tohoto správce. Jelikož jmenovaný velitel není nazýván soudcem (iudex datus), ani žádná další slova v první části nápisu nic o řešení sporu nezmiňují (na rozdíl od druhé části nápisu týkající se řešení pozdější pře) a dále s přihlédnutím $\mathrm{k}$ faktu, že nelze důvodně předpokládat hraniční spor tak krátce po prvotním určení hranic, klonil bych se spíše k závěru, že zde o řešení sporu nešlo.

V této souvislosti je třeba upozornit na nápis 4 , který je v podstatě klonem tohoto nápisu (hranice určuje i stejný velitel). Sloveso determinare, které je v obou nápisech použito nám do věci více světla nevnese, jelikož v nápisech 16 a 21 je použito pro rozhodnutí soudců řešících jednoznačně věc spornou.

63 GALSTERER, H. The administration of justice. In: BOWMAN, A. - CHAMPLIN, E. - LINTOTT, A. (ed.). The Cambridge ancient history. 2. přeprac. vyd. Cambridge: Cambridge University Press, 2010, díl X, s. 404, 405.

64 WILKES, Dalmatia, s. 456.

65 Ex edictu(!) P(ubli) Cor/neli Dolabel(la)e le [g(ati)] / pro pr(aetore) determin[avit] / S(purius?) Titius Geminus / pri(nceps) posterior leg(ionis) / VII inter Neditas / et Corinienses / restituti iussu A(uli) / Duceni Gemini / leg(ati) Augusti pr(o) p[r(aetore)] / per A(ulum) Resium [M]a/ximum I(centurionem) leg(ionis) $X I / C$ (laudiae) p(iae) f(idelis) pr(incipem) posterior(em) / et Q(uintum) Aebutium / Liberalem (h) astat(um) / posteriore(m) leg(ionis) / eiusdem. CIL III 9973, místo nálezu Benkovac, datace 63-68 n. 1. 
Pro titul, jímž byl S. T. Geminus pověřen svým úkolem, nápis použivá nápis slovo edikt (ex edictu). ${ }^{66} \mathrm{~V}$ nápisech 4, 6, 7, 8 a 10 se setkáváme v analogické situaci se slovem dekret (ex decreto). V̌̌echny tyto nápisy se týkají správce Dolabelly. Za těchto okolností mám za to, že ediktem zde není myšlen provinční edikt jako akt normativní, nýbrž individuální rozhodnutí správce, který pověřoval určitou osobu vykonáním nějakého úkolu a tím mu propůjčoval i potřebnou pravomoc.

Druhá část nápisu se týká pozdější soudní pře mezi těmito obcemi, kterou vyřešil svým rozhodnutím správce provincie A. Ducenius Geminus, ${ }^{67}$ prostřednictvím dvou velitelů legie XI C. p. f. (iussu legati per). Obdobná slova nacházíme ještě v nápisech 2, 13 a 14, přičemž v žádném z nich nejsou tito činovníci titulováni (v nápisu 13 navíc nejsou osoby spolupůsobící jmenovány vůbec). Nelze tedy s určitostí říci, že působili coby iudices dati, i když je to, s ohledem na jiné nápisy, pravděpodobné. V každém případě jednalo-li se o řešení sporu a nikoliv o znovuvyměření hranic z moci úřední, byla tato pře řešena v procesu cognitio extraordinaria.

(2) Dalším záznamem o řešení stejného hraničního sporu mezi obcemi Corinium a Nedinum je nápis nalezený v obci Novigrad na území municipia Corinium. ${ }^{68}$ Jedná se o totožné rozhodnutí jako v nápise 1 , část druhá. Totožné jsou obce, o jejichž hranice jde, stejný je správce i oba soudci. Z použitých slov finis inter Neditas et Corinienses derectus mensuris actis ${ }^{69}$ je patrné, že se jedná o úpravu již dříve stanovené hranice, přičemž podkladem pro tuto opravu bylo měření v terénu. Souvislost s předchozím nápisem je dána i použitými slovy pro způsob rozhodnutí (iussu legati per). Pokud šlo o řešení sporu, pak se jednalo o proces kogniční.

(3) Tím se dostáváme k poslednímu nápisu zachycujícímu rozhodování hraničních sporů mezi těmito dvěma obcemi. Jedná se o nápis, který časově předchází oba předchozí. Nápis pochází z funkčního období správce L. Volusia Saturnina, ${ }^{70}$ místo nálezu Obrovac (Corinium). ${ }^{71}$ Datace nápisu dle Heidelberg Database je mezi roky 37-41 n. 1., tedy v období vlády císaře Caliguly, který je na nápisu jmenován. Z pověření správce provincie jako iudex datus rozhoduje hraniční spor mezi municipii Corinium a Nedinum jeden centurion sedmé legie. Obec Nedinium je na nápisu př́mo jmenována. To, že druhou stranou sporu bylo municipium Corinium, lze dovodit z místa nálezu. Obec Obrovac se totiž nachází $\mathrm{v}$ teritoriu, které náleželo $\mathrm{k}$ předmětnému municipiu. Poprvé se setkáváme s titulem iudex datus, z něhož lze dovodit, že šlo o soudní při a tato se rozhodovala v procesu kogničním.

Ze slov ex conventione nelze podle mého názoru usuzovat na to, že spor byl urovnán smírem (jako je tomu u nápisů 5 a 9), nýbrž že soudce byl jmenován se souhlasem stran

66 Jedná se o ortografickou chybu, gramaticky správně by mělo být ex edicto.

67 A. Ducenius Geminus, konsulem v roce cca 56/7 n. 1., funkční období správce provincie Dalmatia v letech cca 63-67 n. 1 .

68 Fin[i]s inter Neditas et Corinienses / derectus mensuris actis iussu / [A(uli) Du]ceni Gemini leg(ati) per A(ulum) Resium / Maximum I(centurionem) leg(ionis) XI principem / posteriorem co(ho)[r(tis)] I et per [Q(uintum)] A[e]butium / Liberalem I(centurionem) eiusdem leg(ionis) (h)astatum / posteriorem c(o) hor(tis) I. CIL III 2883, místo nálezu Novi Grad, datace 63-68 n. 1.

69 „Hranice mezi obcemi Nedinum a Corinium byla opravena po provedeném měření.“

70 L. Volusius Saturninus L. f, konsulem v roce 3 n. 1., funkční období správce provincie Dalmatia před r. 29 do cca 40 n. 1 .

71 -----]nus Laco / [cent(urio)? l]eg(ionis) VII iudex / [--- datu]s ex convent/[ione eo]r(um) ab L(ucio) Volus[io] / Saturnino le [g(ato)] / [p]ro pr(aetore) C(ai) Caesari[s] / [A]ugusti Germ[a]/[ni]ci inter Ned[i]/ [tas et -----. CIL III 2882, místo nálezu Benkovac, datace 37-41 n. 1. 
(iudex datus ex conventione ab L. V. Saturnino legato...). S obdobným př́padem se setkáváme i u nápisu 11.

Obec Corinium figuruje i na dalších nápisech ohledně hraničních sporů. Jedná se o určování hranic s dalšími sousedy. Toto zjištění není překvapivé, vezmeme-li v úvahu, že muncipium Corinium bylo obklopeno pěti municipii na rozlohou poměrně nevelkém území a lze tedy předpokládat, že s nimi mělo společnou hranici.

(4) Tento nápis z Benkovace (Corinium) publikovaný v roce 2003 hovoří o hraničním sporu mezi obcemi Corinium a Asseria (Benkovac). ${ }^{72}$ Obě obce jsou na nápisu jmenovány, o stranách sporu tedy nemůže být pochyb. Rozhodnutí je opět přijato za správce Dolabelly, tedy v letech 14-20 n. 1.

Tento nápis úzce souvisí s nápisem 1, resp. jeho první částí. Hranice určoval (determinavit) též jeden velitel sedmé legie (pokud je v jednom z těchto nápisů ortografická chyba u jména tohoto činovníka, pak se jednalo dokonce o totožnou osobu), jmenován byl ex decreto správce provincie, kterým byl, jako v prvním případě, P. C. Dolabella. Jako u nápisu 1 je na zvážení, zda se jednalo o úkon při prvotní parcelaci (forma Dolabellina) provincie nebo o soudní př̀ řešenou v procesu kogničním.

(5) Nápis nalezený v Obrovaci (Ansium) ${ }^{73}$ řeší hranice mezi municipii Corinium a Ansium (Cvijina Gradina, Obrovac). V mnoha ohledech se podobá rozhodnutí dle nápisu 2. Toto rozhodnutí taktéž učinil správce provincie, již shora zmiňovaný A. Ducenius Geminus (iussu ... legati), po měření v terénu (mensuris actis), i zde se hovoří o opravě již existující hranice (finis ... derectus). Není zde zmínka o soudcích, kteří by spolupůsobili v tomto rozhodovacím procesu, ačkoliv jejich spolupo̊sobení lze předpokládat, už proto, že probíhalo měření v terénu, které jistě nezajišt'oval sám správce. Tito činovníci mohli být jmenováni v nějaké chybějící části nápisu.

Je otázkou, jak vykládat slova secundum conventionem utriusque partis na nápisu uvedená. Wilkes slovní spojení secundum conventionem překládá ,,after a second meeting“",74 mám však za to, že přiléhavější překlad je ,,podle ujednání (dohody) obou stran“. Se slovem conventio se setkáváme též na nápisech 3,11 a 9. Zatímco u nápisu 9 jde o dohodu stran o meritu sporu, na nápisech 3 a 11 se dohoda stran vztahuje podle mého mínění k osobě soudců. Na předmětném nápise 5 by však takový výklad byl obtížný i za předpokladu, že na úplném textu nápisu byl nějaký soudce jmenován. Věta finis ... derectus (est) secundum conventionem utriusque partis je vnitřně konzistentní a stěží si lze představit navázání slov secundum conventionem na jiné větné členy. Vše tedy nasvědčuje tomu, že se zde skutečně zmiňuje dohoda stran ve věci, která se navíc stvrzuje rozhodnutím správce.

Stejně jako u nápisů 1 , druhá část a 2 může vést předmětný nápis $\mathrm{k}$ úvaze, že za tohoto správce byly hranice mezi municipii v oblasti Ravni Kotari řešeny nově, komplexně a že podnět k překreslování hranic vycházel z centra, nikoliv od obcí samotných. Pokud je však tato úvaha mylná a jednalo se o řešení sporu, byl tento řešen v procesu kogničním.

72 Ex [dec(reto) P(ubli) Corn(eli)] / Dol(abellae) leg(ati) pr(o) [pr(aetore)] / det(erminavit) C(aius) Titius / Geminus I(centurio) [---?] / leg(ionis) VII inte[r] / Asser(iates) et C[or(nienses)]. AE 2003, 1332, místo nálezu Obrovac, datace 14-20 n. 1.

73 ---?] / [finis] inter Ansi[enses](?) [et] / [Co]riniens(es) secundum / [c]onventionem utrius/que partis derectus mensu/[ris] actis iussu A(uli) Duceni / [Gem]ini leg(ati) Aug(usti) pro pr(aetore). AE 1910, 79; ILJug 2865; ILS 9378, místo nálezu Obrovac, datace 63-67 n. 1.

74 WILKES, Dalmatia, s. 458. 
(6) Další nápis z Benkovace (Corinium) je torzem. ${ }^{75} \mathrm{Z}$ nápisu se s jistotou dozvídáme pouze to, že se jednalo o vymezení hranice mezi nějakými obcemi v provincii (finis inter) za správce Dolabely. Mohlo se jednat o úkon při prvotním vymezení hranic v provincii nebo o řešení hraničního sporu. Z místa nálezu lze důvodně předpokládat, že jednou stranou sporu bylo municipium Corinium a druhou stranou byla s nejvyšší pravděpodobností obec Nedinum nebo Asseria. ${ }^{76}$

K výše uvedeným šesti nápisům je třeba ještě doplnit základní data vzniku předmětných municipií. Dle závěrů Wilkese obec Corinium se stala municipiem za vlády Augusta, tedy do roku 14 n. 1., zatímco Nedinum nejdříve za vlády Tiberia, ev. až za Claudia (tedy v období 14-54 n. 1.). Asseria nabyla tento status až za vlády císaře Claudia (41-54 n. 1.). ${ }^{77}$ Poslední spor (3) mezi obcemi Corinium a Nedinum se tedy řešil v době, kdy s jistotou obě obce měly již municipální status (za císaře Nerona). V prvním př́ípadě (1) (za císaře Augusta či Tiberia) a v prípadě druhém (2) (za císaře Caliguly) to s jistotou (relativní) platí pouze pro Corinium. Nicméně není vyloučeno, že tento status za správce Dolabelly mělo již i Nedinum (nástup Dolabelly do funkce správce se kryje s nástupem Tiberia na trůn). Tomu nahrává i fakt, že obě obce přímo sousedí v prostoru, kde byla vysoká koncentrace obyvatelstva a obcí. Jeví se jako logické, že určování hranic souvisí právě s udělením municipálního statusu oběma obcím. Tato úvaha však selhává v případě sporu (4) mezi obcemi Corinium a Asseria (za správce Dolabelly 14-20 n. 1.), kdy dle shora uvedené datace J. J. Wilkese byla Asseria ještě značně vzdálena od municipálního statusu. Poslední dotčené municipium Ansium (5) vzniklo za juliovsko-claudiovské dynastie. Bližší určení není na základě dosavadních poznatků možné.

(7 a 8) J. J. Wilkesovi nebyly známy (stejně jako nápis 4) dva nápisy publikované v roce 1995, místo nálezu Rastovac, Bljušćevica-Straža u Trogiru, datace dle HID 14-30 n. 1.78 Jelikož ve věci rozhodoval správce Dolabella, bylo by na místě posunout terminus post quem non na rok 20 n. 1. Zjevně se jedná o torza původních nápisů, a tudíž se nedozvídáme, zda se jednalo o spor či spíše o administrativní rozhodnutí správce provincie související se stanovením vnitřního územního uspořádání provincie (forma Dolabellina). Neobvyklé je označení předmětu rozhodnutím finis novus saltus territorii, které se na jiných nápisech nevyskytuje. ${ }^{79}$

At’ už se jednalo o agendu spornou či nikoliv, nápisy se týkají určení hranic území kmene Tariotů, tedy hranic jejich civitatis. Jednalo se o nové určení těchto hranic, to znamená úpravu stavu již jednou definovaného. O tomto kmeni se zmiňuje Plinius st., který jmenuje též jejich castellum Tariona. ${ }^{80}$ Toto území se nacházelo na pobřeží přibližně mezi městy

75 [E]x dec[reto] / [P(ubli)] Corne[li Do]/label(lae) le [g(ati) pro pr(aetore)] / finis int[er ---] / [---]II[---] / [-----. AE 1910, 80; ILJug 2872, místo nálezu Benkovac, datace 14-20 n.1.

76 Wilkes uvádí, že pravděpodobně jde o spor mezi obcemi Corinium a Nedinum. S ohledem na nápis AE 2003, 1332 (spor mezi Corinium a Asseria), který Wilkesovi nemohl být znám, je však stejně pravděpodobné, že druhou stranou sporu mohlo být jak Nedinum, tak Asseria. WILKES, Dalmatia, s. 257.

77 WILKES, Dalmatia, s. 492.

78 F(inis) n(ovus) sal(tus) te(rritorii) Tar(iotarum) / ex de(creto) P(ubli) Cor(neli) Dol(abellae) / [--] pro [--] AE 1995, 1229, místo nálezu Rastovac - Bljušćevica-Straža, datace 14-30 n. 1.

Sal(tus) te(rritorii) Ta(riotarum) ex d(ecreto) Dol(abellae) leg(ati). AE 1995, 1230, místo nálezu Rastovac - Bljušćevica-Straža, datace 14-30 n. 1.

79 Podst. jm. saltus (zde v genitivu sing.) může znamenat průsmyk, sráz, stráň, údolí, rokle, les, hvozd, ale také pastvinu. Latinsko-český slovník. Praha: SPN, 1957.

$80 \quad$... dein Tariotarum antiqua regio et castellum Tariona... Plin. HN 3, 141. „Dále pak staré království Tariotů a pevnost Tariona..." 
Šibenik a Trogir. Jednalo se o část kmene Delmatů, přičemž před římským ovládnutím Dalmácie nelze hovořit o státní formě jeho života a zmiňované castellum Tariona bylo spíše pevností než městským centrem. ${ }^{81}$ Není zřejmé, v jakém směru se hranice předmětným rozhodnutím vymezovaly, jisté je, že ne směrem jižním a západním, kde hranici tvořilo mořské pobřeží. Směrem východním bylo území coloniae Salonae - hlavního města provincie - a na sever leželo město Rider, nástupce Delminia coby centra Delmatů (pozdější flaviovské municipium) a zde tedy s kmenem Tarionů sousedila jiná delmatská civitas.

Z funkčního období správce Dolabelly se zachovaly ještě dva nápisy urovnávající spory mezi domorodými obcemi.

(9) První nápis, který stvrzuje smírné vyřešení sporu o prŕístup k vodě mezi obcemi Ortoplinů a Parentinů (příslušejících ke kmeni Iapodů), byl nalezen v obci Jablanac u Senje a jeho datace dle HID je 101-200 n. $1 .^{82}$ J. J. Wilkes jej řadí mezi nápisy z doby správce Dolabelly, ${ }^{83}$ což by datace dle HID vylučovala. Najít přesvědčivé argumenty pro správnost jedné $\mathrm{z}$ datací je obtížné a tuto otázku nechávám otevřenou.

Nápis je zajímavý z pohledu jeho možné právní interpretace jako stvrzení soukromoprávní dohody. Nápis je sice zjevně neúplný, nicméně nic v zachovalém textu nenaznačuje, že by v rámci urovnání sporu figurovala státní moc. Nelze tedy vyloučit, že jde o zachycení soukromoprávní dohody bez jejího posvěcení správcem provincie. S ohledem na to, že šlo patrně jen o parciální úpravu hranice, spíše o její vyjasnění a účelem dohody bylo zabezpečit přístup obou obcí k vodě, jeví se takové vysvětlení jako poměrně logické.

(10) Druhý nápis týkající se obce Ortopliniů byl nalezen taktéž v obci Jablanac u Senje a jeho datace dle HID je 14-50 n. $1{ }^{84} \mathrm{~S}$ ohledem na funkční období správce provincie Dolabelly je třeba datum rozhodnutí posunout nejpozději do roku $20 \mathrm{n}$. 1. Obec Begů (J. J. Wilkes ji označuje jako „Beci“) stejně jako Ortoplinů již v dané době musela příslušet ke kmeni Liburnů. Z textu tohoto torzovitého nápisu, který je obdobou nápisu 6 , se mnoho nedovídáme. Šlo o vymezení hranice mezi uvedenými obcemi, přičemž nelze určit, zda se jednalo o spor či prvotní vyměřování hranic v provincii.

(11 a 12) Dvě rozhodnutí ohledně hranic jsou známa z nápisů nalezených mezi řekou Krka a pevností Promona. ${ }^{85}$ Obě rozhodnutí byla vydána za správce L. Volusia Saturnia, zmíněného již shora v nápisu 3.

Ani na jednom nápisu nejsou jmenovány obce, jejichž území se spor týkal. S ohledem na místo nálezu však lze předpokládat, že na jedné straně sporu byla vždy obec Varvarinů, která nabyla statusu municipia za vlády císaře Tiberia. ${ }^{86}$ Pokus o určení druhé strany sporu by byl za hranicí př́pustné spekulace. Datace nápisů je dle HID mezi lety 37-41 n. 1., což

81 WILKES, Dalmatia, s. 184, 330.

82 Ex conventione finis / inter Ortoplinos et Pare/ntinos aditus ad aquam / vivam Ortoplinis pas(s)us / D latus I. CIL III 15053, místo nálezu Jablanac, datace 101-200 n. 1.

83 WILKES, Dalmatia, s. 201 a násl., a 457.

84 Ex dec[r(eto)] / P(ubli) Cornel[i] / Do[[l]]llabel(l)ae / leg(ati) pr(o) pr(aetore) A[ug(usti)] / [[-----]] / int(er) Begos et Ortopli[n(os)]. ILJug 919, místo nálezu Jablanac, datace 14-50 n. 1.

85 --?]/[-Vib]ullius T[---] / [le]g(ionis) VII et L(ucius) Sal[vi]/[us] M(arci) Sueto ce[n]/[t]uriones leg(ionis) $X[I]$ / [iu]dices dati ex / [co]<n>ventione a / [L(ucio) V]olusio Satur/[n]ino leg(ato) pro pr(aetore) / [C(ai)] Caesaris Aug(usti) / [Ger]manici inter / [---] RV[---]. CIL III 9832, místo nálezu Promina, datace 37-41 n. 1 .

[L(ucio)] Volus[io] / [Satu]rnino [leg(ato)] / [pr(o)] pr(aetore) C(ai) C[aes(aris)] / [Aug(usti) G] erm[anici]. CIL III 9833, místo nálezu Promina, datace 37-41 n. 1.

WILKES, Dalmatia, s. 492. 
by znamenalo, že rozhodnutí byla vydána až poté, co se Varvaria stala municipiem (Tiberius zemřel $v$ roce 37 n. 1.).

$\mathrm{Z}$ druhého nápisu, zjevně torzovitého, nelze vyčíst $\mathrm{v}$ podstatě nic, nicméně $\mathrm{z}$ místa nálezu, datace a patrné souvislosti s nápisem č. 11 lze s vysokou mírou pravděpodobnosti dovozovat, že se též jedná o hraniční kámen s nápisem ohledně rozhodnutí hraničního sporu. Zachovaný text je doslova shodný se střední částí nápisu č. 11. Na souvislost nápisu se sporem o hranice usuzoval i J. J. Wilkes, a to patrně ze stejných důvodů. ${ }^{87}$

Text prvního nápisu (též neúplný) sice nehovoří explicitně o hraničním sporu, slovo inter na konci dochovaného textu ovšem jasně naznačuje, jak původní nápis pokračoval. Ze srovnání s ostatními nápisy je více než pravděpodobné, že následoval výčet obcí, jejichž sporné hranice se určují. Cenné na tomto nápisu je naopak to, že jasně označuje dva ve věci činné soudce coby iudices dati. Díky tomu můžeme uzavřít, že šlo o soudní spor řešený v procesu kogničním. Oba soudci, jmenovaní ex conventione účastníků sporu, byli důstojníky v provincii prítomné legie, což je pro daný typ sporu typické.

(13) Za téhož správce provincie padlo rozhodnutí v hraničním sporu dvou menších domorodých obcí z kmene Delmatů. Jednalo se o obce Onastinů (Omiš) a Nerastinů (Jesenice), které se nacházely v prŕímoří jihovýchodně od Salony. ${ }^{88}$

J. J. Wilkes uvádí, že tento spor rozhodl sám správce provincie L. Volusius Saturninus poté, co vyslechl důkazy (,hearing of evidence“) a dále uvádí, že žádný iudex v dané věci nepůsobil, pouze pověřený zástupce správce vytyčil hranice. ${ }^{89}$ Vychází přitom z překladu slovního spojení consilio adhibito jako „hearing of evidence“.

Tento překlad a z toho vyvozované závěry se mi jeví přinejmenším jako sporné. Latinské slovo consilium může mít více významů (základní význam je „radění se, rada, porada, poradní sbor" $),{ }^{90}$ sotva jej však lze překládat slovem „důkaz“. U citovaného slovníkového hesla můžeme nalézt přímo překlad slovního spojení nulli consilio adhibere, a to jako „nepozvati, nepřibrati k žádné poradě“. Máme-li tedy v textu nápisu iis athibito consilio, je podle mého mínění přiléhavější př̌kládat tuto pasáž jako ,poté, co přizval k té poradě““ než ,poté, co vyslechl důkazy“. Otázkou zůstává, koho správce k poradě přizval, zda strany či právě pověřeného L. T. Secunda, který vytyčil hranice (terminos posuit). Kloním se $\mathrm{k}$ tomu, že nápis má na mysli sporné strany. Uvádět tuto skutečnost v př́padě pověřeného činovníka by mi přišlo jako nadbytečné, jelikož poradu mezi ním a správcem je třeba předpokládat v každém př́padě. Navíc zde lze spatřovat jistou podobnost $\mathrm{s}$ nápisem 5 , kdy také rozhodoval správce za součinnosti stran. Každopádně se jedná o rozhodnutí v procesu kogničním.

(14) Další z nápisů zmiňuje spor o hranice pozemků mezi obcí Onastinů (jako v předešlém nápise) a Pituntinů (Podstrana). ${ }^{91}$ Datace nápisu v HID je mezi lety 41-54 n. 1. Jelikož

87 WILKES, Dalmatia, s. 217.

88 L(ucius) Trebius / Secundus pr/aef(e)ctus castr/orum inter / Onastinos et / Narestinos ter/minos pos(u)it ius/ su L(uci) Volusi Satu/rnini leg(ati) pro pr/aetore C(ai) [[C[ae]]]/[s[ar]is A[ugusti]]] / [[G[erm]anici]] ex / senten\{ten\}tila quam $i(i)$ s ath/i<b>ito(!) consi/lio dixit. CIL III 8472, místo nálezu Dugi Rat, datace 37-41 n. 1 .

89 WILKES, Dalmatia, s. 457.

$90 \quad$ Latinsko-český slovník. Praha: SPN, 1957.

91 [-- i]nter Ner[a]/[sti]nos et Pitunti/nos termini r[ec]/[o]gniti et restitu[ti] a / [P]isone leg(ato) pro pr(a)etore / [Ti(beri)] Claudi Caesaris [Aug(usti)] / Germanici per C(aium) Ma[r]/ium Maternum I(centurionem) leg(ionis) / VII C(laudiae) p(iae) f(idelis) quos L(ucius) Volus/[ius Saturninus leg(atus) pro] / [pr(aetore) statuendos? curaverat]. CIL III 12794, místo nálezu Omiš, datace 41-54 n. 1. 
víme, že rozhodnutí bylo přijato za správce L. C. Pisona, přidržím se datování vymezeného dobou výkonu jeho funkce (43-46, ev. 50 n. 1.). ${ }^{92}$

Jedná se opět o standardní kogniční proces, kdy rozhoduje správce prostřednictvím pověřené osoby ( legato per), centuriona sedmé legie, který pravděpodobně působil jako iudex datus pověřený správcem provincie, i když z nápisu se to explicitně nepodává.

Nápis zmiňuje i předchozí rozhodnutí o hranicích těchto obcí, které bylo vydáno již za správce L. V. Saturnina. Rozhodnutí správce Pisona tedy bylo úpravou či zpřesněním předchozího rozhodnutí o hranicích těchto obcí (termini recogniti et restituti), které bylo učiněno několik málo let před tím.

(15) Další nápis řeší hraniční spor mezi obcemi Sidrona (Medvidja) a Asseria (Benkovac). ${ }^{93}$ Datace nápisu dle HID je 42-69 n. 1., místo nálezu Benkovac - Bruška. J. J. Wilkes správně poukazuje na souvislost $\mathrm{s}$ nápisem 2. Tato souvislost spočívá $\mathrm{v}$ tom, že spor rozhodoval stejný soudce jako ve sporu dle nápisu 2 , kde rozhodoval ve dvojici. Nelze z toho však podle mého mínění automaticky dovozovat, že k tomu došlo i za stejného správce, jako to činí J. J. Wilkes, který nápis řadí do období, kdy správcem provincie byl A. Ducenius Geminus, zmíněný již shora v nápisech 1 a 5 .

Z torzovitého nápisu můžeme přesvědčivě dovodit, že šlo o hraniční spor (inter ... definit). Co jiného by určoval či vymezoval jmenovaný Q. A. Liberalis než hranice mezi obcemi? Šlo tedy o hraniční spor, který se rozhodoval opět v procesu cognitio extraordinaria.

(16) Další spor o hranice, tentokrát mezi municipii Asseria a Alveria, proběhl za správce Pompeia Silvana. ${ }^{94} \mathrm{~S}$ nejvyšší pravděpodobností šlo o spor hraniční (spor mezi sousedícími obcemi, použité sloveso determinare). ${ }^{95}$

Způsob řešení sporu se odlišuje od dosud diskutovaných nápisů v několika směrech. Jednak spor nerozhodovali vojenští velitelé, nýbrž coby iudices dati byly jmenovány civilní osoby, pravděpodobně z řad městské nobility jiných než sporem dotčených měst. Neobvyklý je i počet čtyř soudců. Dosud jsme se setkali s př́pady, kdy rozhodoval jeden či dva soudci. Nová jsou i slova per sententiam (suam) determinaverunt, která naznačují, že soudci ve věci, po jejím prošetření, sami rozhodli, přičemž správce do rozhodování nijak nezasahoval. Nelze přehlédnout věcnou souvislost s nápisem 19, kdy též rozhodovala ve věci civilní osoba, a to vlastním rozsudkem na základě pověření správcem (ut diceret sententiam).

Tento proces by tedy mohl být svojí formou považován za proces formulový, byt' ne vedený v jeho čisté formě. Proti tomu však hovoří fakt, že soudci jsou v nápisu výslovně nazýváni jako iudices dati. Důvodem pro jmenování civilních osob za soudce na místo tradičních legionářů může být to, že v předmětné době provincii opouštěla legie IX (legie VII již odešla dříve), která sice byla nahrazena legií IV, setrvavší až do roku 86 n. 1., nicméně se

92 (L. Calpurnius?) Piso (Cn. f.?), konsulem v roce 27 n. 1., funkční období správce provincie Dalmatia po roce $43 \mathrm{n} .1$.

93 [-----](?) / [-----] / [---] Caesaris Au[g(usti) ---] / inter Sidrinos et / Asseriates Q(uintus) Aebu/tius Liberalis I(centurio) leg(ionis) / XI definit. AE 1905, 164; ILJug 2845; ILS 9379, místo nálezu Benkovac, datace $42-69$ n. 1.

94 M. Pompeius Silvanus, konsulem v roce 45 n. 1., funkční období správce provincie Dalmatia v letech 67-70 n. 1 .

95 [Ti(berius)] Claudius Epetinus / C(aius) Avillius Clemens / L(ucius) Coelius Capella P(ublius) / Raecius Libo P(ublius) Valerius / Secundus iudices dati a M(arco) Pom[peio] /Silvano leg(ato) Aug(usti) pro pr(aetore) inter $r(\mathrm{em}) \mathrm{p}$ (ublicam) / Asseriatium et inter rem $p$ (ublicam) Alve[ritarum] / in re praesenti per sententiam [suam] / determinaverunt. AE 2003, 1333, místo nálezu Benkovac, datace 69-70 n. 1. 
mohlo jednat o určité interregnum, kdy si objektivní okolnosti vynutily takovéto opatření. To, že praxe povolávání vojenských velitelů k rozhodování hraničních sporů nevymizela, dokládá o něco pozdější nápis 17.

(17) Nápis nalezený v Zadaru a datovaný v HID lety 70-79 n. $1 .{ }^{96}$ nám neříká explicitně, že jde o spor o hranice, je to nicméně pravděpodobné. Spor rozhoduje vojenský velitel IV legie coby iudex datus. J. J. Wilkes dovozuje (ze slov ex auctoritate imperatoris), že při řešení sporu byl činný přímo císař Vespasiánus, který soudce jmenoval namísto správce Pegasa. ${ }^{97}$ Takový výklad se mi jeví jako odvážný a spíše mám za to, že se slova ex autoritate imperatoris vztahují na vojenskou funkci C. P. Firma (tribunus militum) než k samotné osobě soudce v dané kauze. Tomuto výkladu nahrává i použitá ablativní spojka a v témže pádovém tvaru uvedené jméno správce (a Lucio Plocio Pegaso), které jasně naznačují jmenování soudce ze strany správce, jak ostatně bylo zvykem. O kogničním charakteru daného procesu sotva může být sporu.

Následují dva nápisy, které řeší hranice mezi domorodými obcemi.

(18) Za správce L. Arruntia Camilla Scriboniana ${ }^{98}$ byl řešen spor mezi obcemi Sapuatů a Lamatinů, kdy tyto obce náležely bud' ke kmenu Ditionů nebo Maezaeiů. ${ }^{99}$ Nápis byl nalezen ve městě Jajce a je datován v HID lety 40-41 n. 1. Spor řeší z pověření správce provincie jeden centurion coby iudex datus (iudicem dedit). Za pozornost stojí použité slovní spojení ... ut fines regeret et terminos poneret, ${ }^{100}$ se kterým se na jiných nápisech nesetkáváme. Spornost je v tomto případě jasně vyjádřena slovesem regere, které znamená obnovu porušeného stavu. Charakter procesu je nepochybně cognitio extraordinaria.

(19) Druhým nápisem řešícím hraniční při domorodých obcí je nápis nalezený v obci Vrlika. ${ }^{101}$ Datace dle HID je v rozmezí $1-150$ n. 1. Správce Bassus je znám pouze z tohoto nápisu a nelze tuto osobu s jistotou ztotožnit ani za pomoci prosopografie, J. J. Wilkes jej řadí do přehledu správců provincie pod pořadovým číslem 40, ale uvádí ho mezi správci nejasné datace a u tohoto správce dodává „no ready identification“. 102

Spor byl mezi dvěma obcemi přináležejícími ke kmeni Delmatů. Správce Bassus, dle předmětného nápisu, pověřil ve věci sporu o hranice (in negotio finali) jistého C. P. Maxima, aby rozhodl v tomto sporu (C. P. Maximum iudicare iussit). Rovněž mu nařídil (praecepit), aby vynesl rozsudek (ut diceret sententiam) o meznících, které mají být postaveny, resp. umístěny (de ponendis terminis). Zajímavá jsou jednak některá použitá slova a slovní spojení, která se v jiných nápisech nevyskytují, jednak i to, že soudce není vojenským

96 C(aius) Petillius Firm[us] / trib(unus) mil(itum) leg(ionis) IIII F(laviae) [f(elicis)] / ex auctoritate / Imp(eratoris) Vespasian[i] / iudex datus a [L(ucio)?] / [Plo?]/tio Pegaso l[eg(ato) pr(o) pr(aetore)] / [Imp(eratoris)] Vespasian[i Aug(usti)] / [-----. AE 1983, 744; ILJug 945, místo nálezu Zadar, datace 70-79 n. 1.

97 WILKES, Dalmatia, s. 458

98 L. Arruntius M. Camillus Scribonianus, konsulem v roce 32 n. 1., funkční období správce provincie Dalmatia v letech 40-42 n. 1 .

99 L(ucius) Arruntius / Cami[ll]us Scri/b[o]nia[n]us le[g(atus)] pro / pr(aetore) C(ai) [C]ae[s]aris Aug(usti) / Germanici iudicem / dedit M(anium) Coelium /(centurionem) / leg(ionis) VII inter Sapuates / e[t La]matinos(?) ut fines / [reg]eret et termin $<o>s$ po[n(eret)]. CIL III 9864a, místo nálezu Jajce, datace 40-41 n. 1.

$100 \quad$ „... aby vrátil zpět hranice a umístil na ně mezníky.“

101 ------?] / [---]V[---] / [--]s Bassus [---] / inter Barizani[ates et] / Lizaviates in nego[tio] / finali C(aium) Plotium Ma[xi]/mum iudicare iussit / [---]a p[ra]ecepit ut / [diceret se]ntentiam / [de ponendis ter]minis. ILJug 758, místo nálezu Vrlika, datace 1-150 n. 1. 
velitelem a není ani označen coby iudex datus. Navíc jeho pověření ze strany správce není pouze $\mathrm{k}$ prrípravě rozhodnutí, ale přímo $\mathrm{k}$ vynesení rozsudku. To vše vede $\mathrm{k}$ úvaze, zda se v daném př́ípadě nejedná o př́klad sporu řešeného v procesu formulovém.

(20) Nápis pocházející z období vlády císaře Trajána je administrativním úkonem, a nikoli soudním rozhodnutím. ${ }^{103}$ Císařský prokurátor určil hranice (umístil mezníky) mezi vojenským prostorem v Burnumu a lesními pozemky. Není zde ani zmínka o pověření ze strany správce provincie a lze předpokládat, že prokurátor byl činný na základě vlastní moci svěřené mu císařem. Místem nálezu je obec Biskupija u Kninu, datace dle HID je mezi lety 88-96 n. 1.

Jak uvádí J. J. Wilkes, nejednalo se patrně o ojedinělou akci, když stát se snažil udržet kontrolu nad vojenskými pozemky, a to i v době, kdy už zde nebyly umístěné žádné legie. Taková půda mohla být využita k usazení legionářů nebo k založení nové coloniae, jako tomu bylo patrně v př́ípadě založení kolonie Aequum, která se nacházela v blízkosti vojenské stanice Tilurium. ${ }^{104}$ Zde se jednalo nepochybně o prokurátora spadajícího pod res privata, kam patřila správa nemovitého státního majetku.

(21) Posledním nápisem z kategorie hraničních sporů je poměrně pozdní nápis nalezený v oblasti u obce Glamoč. ${ }^{105}$ Datace nápisu dle HID je mezi lety 281-284 n. 1. Z nápisu se dozvídáme, že iudex datus, jehož jméno se nezachovalo, určil hranice mezi obcemi Slavium (Glamoč) a Stridon (umístění sporné, snad Bosansko Grahovo). Správcem provincie, který ho ustanovil do funkce, byl pozdější císař Constantius. V této době již sotva lze uvažovat o jiném typu procesu než cognitio extraordinaria.

Z rozboru shora uvedených nápisů je možné učinit následující závěry. V první řadě lze na základě provedeného výzkumu uzavřít, že s výjimkou nápisů 9 (mimosoudní dohoda), 19 (možný proces formulový) a 20 (rozhodnutí fiskálního prokurátora) jde vždy o rozhodnutí správce, resp. jeho pomocníků, at’ už administrativní povahy (prvotní vyměřování hranic, jejich revize) či soudní (řešení hraničních sporů). Soudní pře jsou rozhodovány (s možnou výjimkou shora uvedenou) v procesu kogničním, a to i v období raného principátu. Tento poznatek zcela nekoresponduje s obecnými závěry současné romanistiky, jak bylo shora naznačeno. Nicméně poznatky získané tímto výzkumem nelze přeceňovat z hlediska možnosti jejich zobecňování. Nelze přehlédnout, že se bezvýhradně jedná o jeden typ soudního sporu, a to sporu o hranice mezi municipii či domorodými obcemi. Takové spory mají sice jisté rysy povahy soukromoprávní, převažují v nich však prvky veřejnoprávní, které patrně byly určující při výběru typu procesu ze strany správce při naplňování jeho impéria na území provincie. Na základě shora uvedené analýzy dochovaných nápisů však lze podle mého mínění učinit závěr o tom, že proces kogniční nebyl ani v 1. století n. 1 . v rímských provinciích v soudním procesu raritou.

Výše uvedené spory a jejich řešení právními prostředky jsou, myslím, dobrým argumentem do diskuse o pozitivním či negativním vlivu římské vlády na porobené provincie. Jedná se o ukázku toho, jak proslulý „ř́ímský mír“ (pax romana) působil v běžném

\footnotetext{
103 [Termini p]o[s(iti) inter p]ra/ta leg(ionis) [e]t fines / roboreti Fla(vi) / Marc(iani) per Augu/stianum Belli/ c(i?) um proc(uratorem) / Aug(usti). CIL III 13250, místo nálezu Biskupija, datace 88-96 n. 1.

104 WILKES, Dalmatia, s. 105.

105 -----] iu[d]ex [d]a[t]us a [F]la/vio Va[ler]io Cons/[t]a[nt]io [v(iro) c(larissimo)] p(raeside) p(rovinciae) [D]elm(atiae)(!) / [f]i[ne]s i[nt]e[r] Salv/ia[t]as e[t] S[tr]ido/[n]e[n]ses [d]e[t][r]m/i[n]avi[t]. CIL III 9860, místo nálezu Glamoč, datace 281-284 n. 1 .
} 
životě. Spory o hranice mezi sousedícími kmeny jsou jistě od nepaměti jedním z typických a frekventovaných konflikti̊, kvůli kterým se prolévá krev. Lze důvodně předpokládat, že i v těchto případech by domorodci, bez přítomnosti Rímanů, řešili věc válečným konfliktem. Vzhledem k etatizaci území, byt' vnucené cizí mocí, však byli nuceni spor řešit právními prostředky a konečnému rozhodnutí se podřídit. O pozitivním vlivu tohoto přechodu od soukromé války a jiných forem svépomoci ke kultivovanějším formám spolužití zprostředkovanými státní mocí na kvalitu života a prosperitu daného společenství lze jen stěží pochybovat.

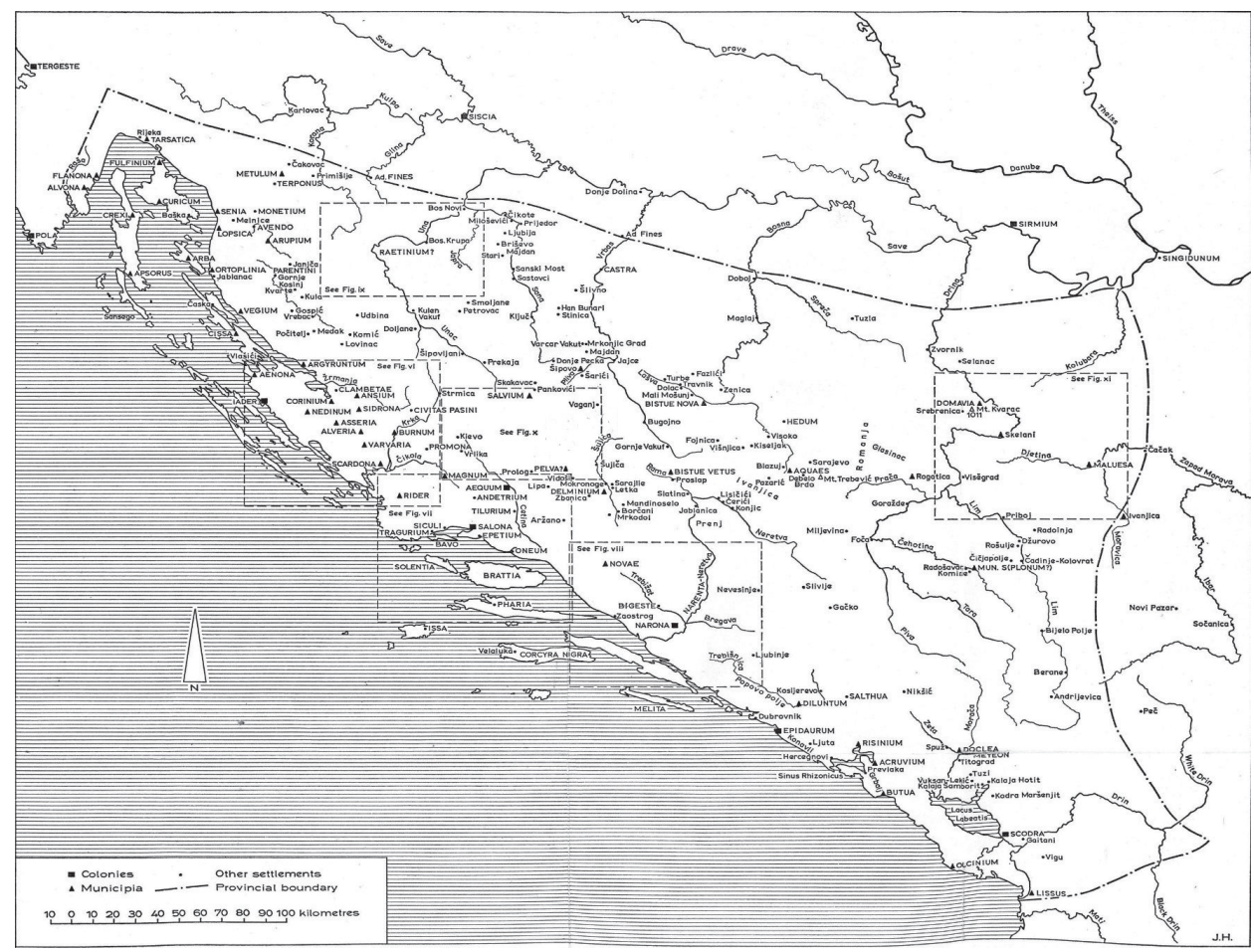

Mapa římské provincie Dalmatia mezi 1-3 stol. n. 1. Převzato z: WILKES, J. J. Dalmatia. London: Routledge \& Kegan Paul, 1969, obr. 25. 